\title{
Desymmetrization of a meso allylic acetal by enantioselective conjugate elimination
}

\author{
Ling $\mathrm{Xu},{ }^{\dagger, \neq}$ Thomas Regnier, ${ }^{\dagger}$ Loïc Lemiègre, ${ }^{\dagger}$ Pascal Cardinael, ${ }^{\ddagger}$ Jean-Claude \\ Combret, ${ }^{\ddagger}$ Jean-Philippe Bouillon, ${ }^{\ddagger}$ Jérome Blanchet, ${ }^{\S}$ Jacques Rouden, ${ }^{\S}$ Anne \\ Harrison-Marchand, ${ }^{\dagger}$ and Jacques Maddaluno ${ }^{\dagger, *}$ \\ ${ }^{\dagger}$ Laboratoire des Fonctions Azotées \& Oxygénées Complexes de l'IRCOF, UMR CNRS 6014, Université et INSA \\ de Rouen, 76821 Mont Saint-Aignan Cedex, France \\ ${ }^{\ddagger}$ Sciences et Méthodes Séparatives, EA 3233, IRCOF, Université de Rouen, 76821 Mont Saint-Aignan Cedex, \\ France \\ ${ }^{\S}$ Laboratoire de Chimie Moléculaire et Thio-Organique, ENSICAEN, Université de Caen Basse-Normandie, \\ UMR CNRS 6507, 6 Boulevard du Maréchal Juin, 14050 Caen, France
}

jmaddalu@crihan.fr 


\section{Table of contents}

$\begin{array}{ll}\text { Title and authors } & \text { S1 }\end{array}$

$\begin{array}{ll}\text { Table of contents } & \text { S2 }\end{array}$

$\begin{array}{ll}\text { Materials and methods } & \text { S2 }\end{array}$

$\begin{array}{lr}\text { Synthesis and data of compounds } \mathbf{9 , 1 0} \text { and } \mathbf{7} & \text { S3 }\end{array}$

Typical procedure for the enantioselective $\delta$-elimination: from $\mathbf{7}$ to $\mathbf{1 2} \quad \mathrm{S} 4$

${ }^{1} \mathrm{H},{ }^{13} \mathrm{C}$ NMR spectra of compounds $\mathbf{9 , 1 0 , 7}$ and $\mathbf{1 2} \quad$ S4-S6

\section{Materials and Methods}

Tetrahydrofuran (THF), toluene and diethylether (ether) were dried from sodium/benzophenone. All reagents were of reagent grade and were used as such or distilled prior to use. Reactions were monitored by thin-layer chromatography (TLC) carried out on $0.25 \mathrm{~mm}$ E. Merck 5735 Kieselgel silica gel coated aluminium plates (60 F254) using UV light as visualizing agent and $7 \%$ ethanolic phosphomolybdic acid, aqueous $\mathrm{KMnO}_{4}$ or ninhydrin solution and heat as developing agents. E. Merck silica gel (60, particle size $0.040-0.063 \mathrm{~mm})$ was used for flash chromatography. ${ }^{1} \mathrm{H}$ and ${ }^{13} \mathrm{C}$ NMR spectra were recorded at room temperature at $300 \mathrm{MHz}$ and 75 $\mathrm{MHz}$ respectively and calibrated using residual undeuterated solvent as an internal reference. The solvent was deuteriochloroform, unless otherwise noted. Chemical shifts $(\delta)$ are given in parts per million (ppm) and the coupling constants $(J)$ in hertz $(\mathrm{Hz})$. The following abbreviations were used to designate the multiplicities: $\mathrm{s}=$ singlet, $\mathrm{d}=$ doublet, $\mathrm{t}=$ triplet, $\mathrm{q}=$ quartet, $\mathrm{qt}=$ quintet, $\mathrm{hp}=$ heptuplet, $\mathrm{m}=$ multiplet, $\mathrm{br}=$ broad. IR spectra were recorded by transmission on a IRTF spectrometer. Optical rotations were recorded at $20{ }^{\circ} \mathrm{C}$ on a polarimeter using the sodium D line $(589 \mathrm{~nm})$ and $[\alpha]_{\mathrm{D}}$ are given in units of $10^{-1} \mathrm{deg} \mathrm{cm}^{-2} \mathrm{~g}^{-1}$. The mass spectra were obtained under electron impact conditions (EI) at $70 \mathrm{eV}$ ionizing potential; $i$-butane ( $\left.{ }^{\mathrm{i}} \mathrm{BuH}\right)$ was used for chemical ionization (CI). Melting points (m.p.) are uncorrected and were measured using a microscope apparatus. Elemental analyses were performed with an analyser. The reference given at the end of each protocol sends back to the previous description of the same compound. 


\section{4-Bromobut-2-enal dimethyl acetal 9}

$$
\overbrace{\mathrm{OMe}}^{\mathrm{OMe}}
$$

Under argon atmosphere, 1-acetoxy-1,3-butadiene $8(1.10 \mathrm{~g}, 10.0 \mathrm{mmol})$ was dissolved in a mixture of dry THF $(5 \mathrm{~mL})$, methanol $(5 \mathrm{~mL})$ and 2,2-dimethoxypropane $(10 \mathrm{~mL})$. N-Bromosuccimide $(1.90 \mathrm{~g}, 10.5 \mathrm{mmol})$ was added at room temperature. The reaction mixture was stirred for 1 hour, and quenched by a solution of saturated aqueous $\mathrm{NaHCO}_{3}(20 \mathrm{~mL})$. The aqueous phase was extracted with diethylether $(3 \times 20 \mathrm{~mL})$, and dried with $\mathrm{MgSO}_{4}$. After evaporation, a dark orange oil was obtained (yield: 99\%). This compound was used for the next step without further purification. Rf: 0.62 (cyclohexane/AcOEt 75:25); ${ }^{1} \mathrm{H}$ NMR $(300 \mathrm{MHz}) \delta 3.32(6 \mathrm{H}, \mathrm{s}), 3.90$ $(2 \mathrm{H}, \mathrm{d}, J=7.5), 4.74(1 \mathrm{H}, \mathrm{d}, J=4.5), 5.65(1 \mathrm{H}, \mathrm{dd}, J=4.5$ and 15.5$), 5.96(1 \mathrm{H}, \mathrm{dt} J=7.5$ and 15.5$)$. The NMR spectrum is identical to the one described in the literature. ${ }^{1}$

\section{4-(4-Methoxybenzyloxy)but-2-enal dimethyl acetal $10^{2}$}<smiles>COc1ccc(COC/C=C/C(OC)OC)cc1</smiles>

To a dispersion of $\mathrm{KH}(1.1 \mathrm{~g}, 27.5 \mathrm{mmol})$ in THF $(40 \mathrm{~mL})$ was slowly added a solution of $p$-methoxybenzyl alcohol $(1.4 \mathrm{~g}, 10.0 \mathrm{mmol})$ in THF $(20 \mathrm{~mL})$. After the dihydrogen bubbling was ended, the reaction mixture was cooled to $0{ }^{\circ} \mathrm{C}$ and a solution of compound $9(1.9 \mathrm{~g}, 10.0 \mathrm{mmol})$ in THF $(20 \mathrm{~mL})$ was added. After stirring at room temperature overnight, the reaction was quenched with water $(15 \mathrm{~mL})$ carefully. The aqueous phase was extracted with ethyl acetate $(3 \times 30 \mathrm{~mL})$ and the resulting organic phase was dried with $\mathrm{MgSO}_{4}$ and concentrated under vacuum. The crude product was purified by flash column chromatography on silica gel (eluent: cyclohexane/ethyl acetate 10:1) affording $1.9 \mathrm{~g}$ (yield: $76 \%$ ) of the pure product $\mathbf{1 0}$ as a light yellow oil. Rf: 0.56 (cyclohexane/AcOEt 75:25); ${ }^{1} \mathrm{H}$ NMR $(300 \mathrm{MHz}) \delta 3.25(6 \mathrm{H}, \mathrm{s}), 3.76(3 \mathrm{H}, \mathrm{s}), 3.96(2 \mathrm{H}, \mathrm{d}, J=5.3), 4.38(2 \mathrm{H}, \mathrm{s})$, $4.74(1 \mathrm{H}, \mathrm{d}, J=4.8), 5.67(1 \mathrm{H}, \mathrm{dd}, J=4.8$ and 15.5$), 5.88(1 \mathrm{H}, \mathrm{dt}, J=5.3$ and 15.5$), 6.80(2 \mathrm{H}, \mathrm{d}, J=8.6), 7.20$ $(2 \mathrm{H}, \mathrm{d}, J=8.6) ;{ }^{13} \mathrm{C}$ NMR $(75 \mathrm{MHz}) \delta 52.9,55.5,69.5,72.1,102.7,113.9,128.9,129.6,129.8,130.4,131.6$. IR (film) $v 2996,2835,1613,1514,1464,1249,1120,1050 \mathrm{~cm}^{-1}$; MS m/z (\%) 137 (38), 121 (100). Anal. Calcd. for $\mathrm{C}_{14} \mathrm{H}_{20} \mathrm{O}_{4}$ : C 66.60, H 7.99. Found: C 66.64, H 7.90.

syn 3-[3-(4-Methoxybenzyloxy)propenyl]-1,5-dimethyl-benzo[e]-[1,3]dioxepane 7.<smiles>COc1ccc(COC/C=C/C2OC(C)c3ccccc3C2C)cc1</smiles>

A catalytic amount of camphorsulfonic acid (CSA) was added, under argon atmosphere, to a solution of compound $10(252 \mathrm{mg}, 1.0 \mathrm{mmol})$ and meso 1,2-bis(1-hydroxyethyl)benzene 11 (250 $\mathrm{mg}, 1.5 \mathrm{mmol})$ in dichloromethane $(5 \mathrm{~mL})$. The reaction mixture was stirred at room temperature for 4 hours and quenched with a saturated solution of sodium bicarbonate $(5 \mathrm{~mL})$. The aqueous phase was extracted with dichloromethane $(3 \times 7$ $\mathrm{mL}$ ) and the resulting organic layers were dried with $\mathrm{MgSO}_{4}$. After evaporation under reduced pressure, the residue was purified by flash column chromatography on silica gel (eluent: cyclohexane/ethyl acetate 8:1) affording $284 \mathrm{mg}$ (yield: 82\%) of the pure product 7 as a colorless oil. Rf: 0.33 (cyclohexane/AcOEt 75:25); ${ }^{1} \mathrm{H}$ NMR $(300 \mathrm{MHz}) \delta 1.66(6 \mathrm{H}, \mathrm{d}, J=6.4), 3.76(3 \mathrm{H}, \mathrm{s}), 3.97(2 \mathrm{H}, \mathrm{d}, J=5.3), 4.40(2 \mathrm{H}, \mathrm{s}), 5.12(2 \mathrm{H}, \mathrm{q}, J=6.4)$, $5.58(1 \mathrm{H}, \mathrm{d}, J=4.2), 5.76(1 \mathrm{H}, \mathrm{ddt}, J=1.3,4.2$ and 15.8$), 5.96(1 \mathrm{H}, \mathrm{dt}, J=5.3$ and 15.8$), 6.79(2 \mathrm{H}, \mathrm{d}, J=8.6)$, 7.19-7.35 (6H, m); ${ }^{13} \mathrm{C}$ NMR $(75 \mathrm{MHz}) \delta 18.9,20.6,54.7,56.6,72.4,74.5,107.2,109.7,113.0,115.2,124.4$, $126.4,126.9,128.0,128.7,129.2,129.6,130.7,142.5,160.2 ; \mathrm{MS} \mathrm{m} / z$ (\%) 354 [M+] (1), 147 (17), 133 (67), 121 (100). HRMS (ESI): calcd. for $\mathrm{C}_{22} \mathrm{H}_{26} \mathrm{NaO}_{4} \mathrm{~m} / \mathrm{z} 377.1729$. Found: 377.1732 .

(1) Gaonac'h, O.; Maddaluno, J.; Chauvin, J.; Duhamel, L. J. Org. Chem. 1991, 56, 4045-4048.

(2) Bataille, C.; Bégin, G.; Guillam, A.; Lemiègre, L.; Lys, C.; Maddaluno, J.; Toupet, L. J. Org. Chem. 2002, 67, $8054-8062$. 


\section{Typical procedure for the enantioselective $\delta$-elimination: from 7 to 12}

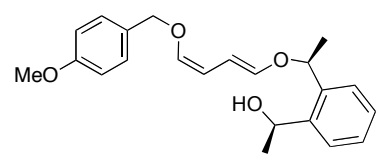

$s \operatorname{BuLi}\left(1.3 \mathrm{~mol} . \mathrm{L}^{-1}\right.$ in cyclohexane, $\left.40 \mu \mathrm{L}, 0.052 \mathrm{mmol}\right)$ was added dropwise at $-78{ }^{\circ} \mathrm{C}$ and under argon atmosphere, to a solution of (-)-sparteine $(12 \mathrm{mg}, 0.051 \mathrm{mmol})$ in $\mathrm{Et}_{2} \mathrm{O}(2 \mathrm{~mL})$. After 10 minutes, a solution of compound $7(9.0 \mathrm{mg}, 0.025 \mathrm{mmol})$ in $\mathrm{Et}_{2} \mathrm{O}(1 \mathrm{~mL})$ was introduced and the resulting mixture was stirred for 3 hours at $-78{ }^{\circ} \mathrm{C}$. The reaction was quenched with a saturated aqueous $\mathrm{NaHCO}_{3}$ solution $(2 \mathrm{~mL})$ and the aqueous layer was extracted with diethylether $(3 \times 3 \mathrm{~mL})$. The resulting organic phase was dried with $\mathrm{MgSO}_{4}$, and evaporated under reduced pressure. The residue was purified by preparative thin layer chromatography (eluent: cyclohexane/AcOEt 3:1) affording $7.1 \mathrm{mg}$ (yield: 72\%, ee 64\%) of the desired product 12 as a colorless oil. $\mathrm{R} f$ : 0.67 (cyclohexane/AcOEt 50:50); ${ }^{1} \mathrm{H}$ NMR (300 MHz) $\delta 1.43(3 \mathrm{H}, \mathrm{d}, J=6.4), 1.50(3 \mathrm{H}, \mathrm{d}, J=6.4), 1.60-1.75$ $(1 \mathrm{H}, \mathrm{br} \mathrm{s}), 3.76(3 \mathrm{H}, \mathrm{s}), 4.70(2 \mathrm{H}, \mathrm{s}), 4.88(1 \mathrm{H}, \mathrm{dd}, J=6.0$ and 11.5$), 5.22-5.29(2 \mathrm{H}, \mathrm{m}), 5.83(1 \mathrm{H}, \mathrm{d}, J=6.0)$, $5.88(1 \mathrm{H}, \mathrm{dd}, J=11.5$ and 12.0$), 6.33(1 \mathrm{H}, \mathrm{d}, J=12.0), 6.87(2 \mathrm{H}, \mathrm{d}, J=8.4), 7.10-7.30(6 \mathrm{H}, \mathrm{m})$. HPLC analyses: Chiralpak OD* $(25 \mathrm{~cm} \times 4.6 \mathrm{~mm})$; eluent: heptane/isopropanol 90:10 (v/v); flow rate: $1.0 \mathrm{~mL} / \mathrm{min}$; temperature: $25{ }^{\circ} \mathrm{C}$; monitored at $\mathrm{UV}$ at $230 \mathrm{~nm}$. (+)-Enantiomer: retention time: $21.0 \mathrm{~min} .[\alpha]_{\mathrm{D}}=+0.062\left(c 0.72, \mathrm{CHCl}_{3}\right)$. HRMS: calcd for $\mathrm{C}_{22} \mathrm{H}_{26} \mathrm{NaO}_{4} \mathrm{~m} / \mathrm{z} 377.1729$. Found: 377.1728 . (-)-Enantiomer: retention time: $8.9 \mathrm{~min}$. $[\alpha]_{\mathrm{D}}=-$ 0.030 ( $c 0.46, \mathrm{CHCl}_{3}$ ). HRMS (ESI): calcd for $\mathrm{C}_{22} \mathrm{H}_{26} \mathrm{NaO}_{4} \mathrm{~m} / \mathrm{z} 377.1729$. Found: 377.1736 .

\section{${ }^{1} \mathrm{H}$ and ${ }^{13} \mathrm{C}$ NMR spectra of compounds $9,10,7$ and 12}

${ }^{1} \mathrm{H}$ NMR $\left(\mathrm{CDCl}_{3}, 300 \mathrm{MHz}\right)$ of 9

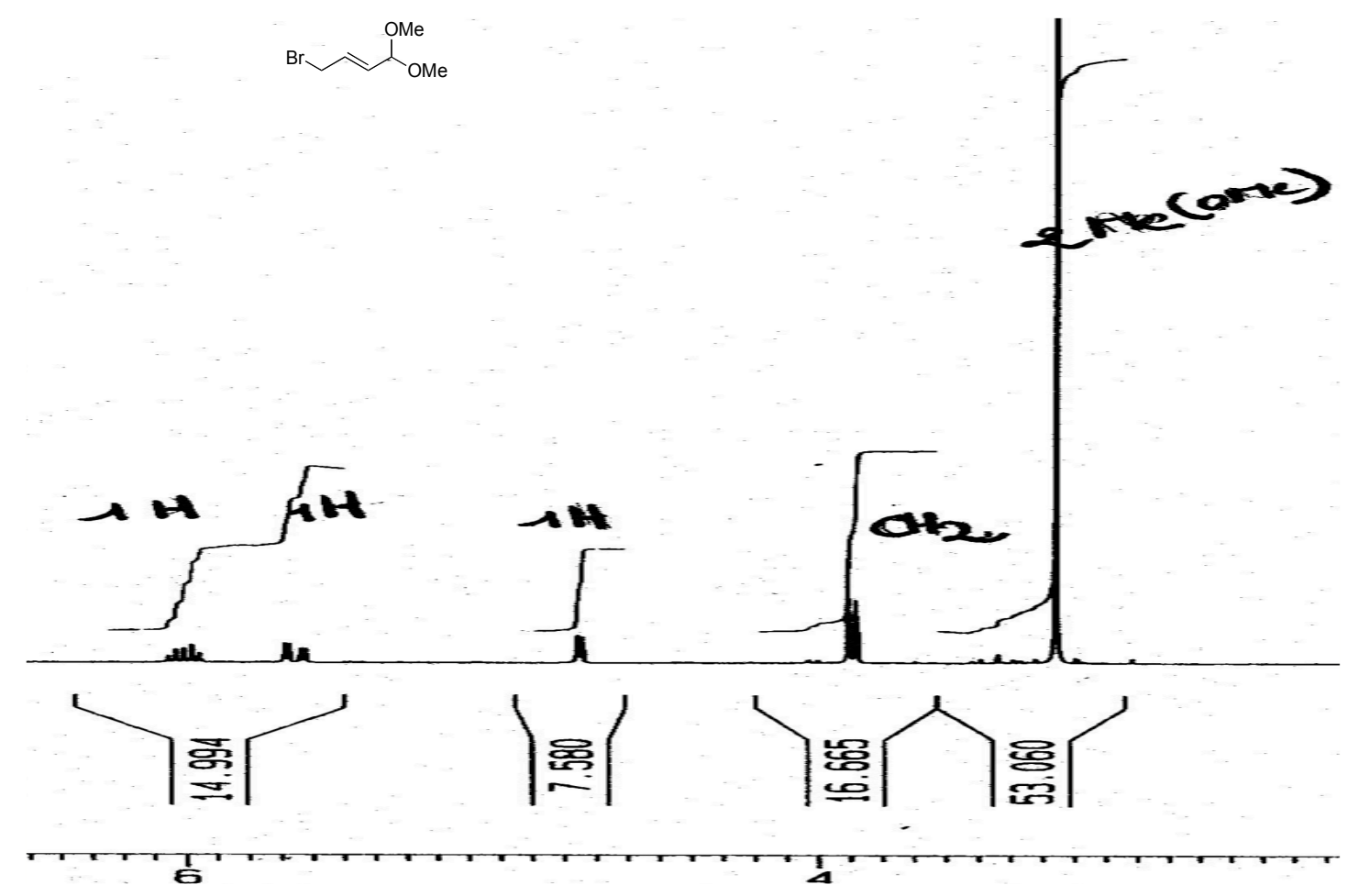


${ }^{1} \mathrm{H}$ NMR $\left(\mathrm{CDCl}_{3}, 300 \mathrm{MHz}\right)$ of $\mathbf{1 0}$

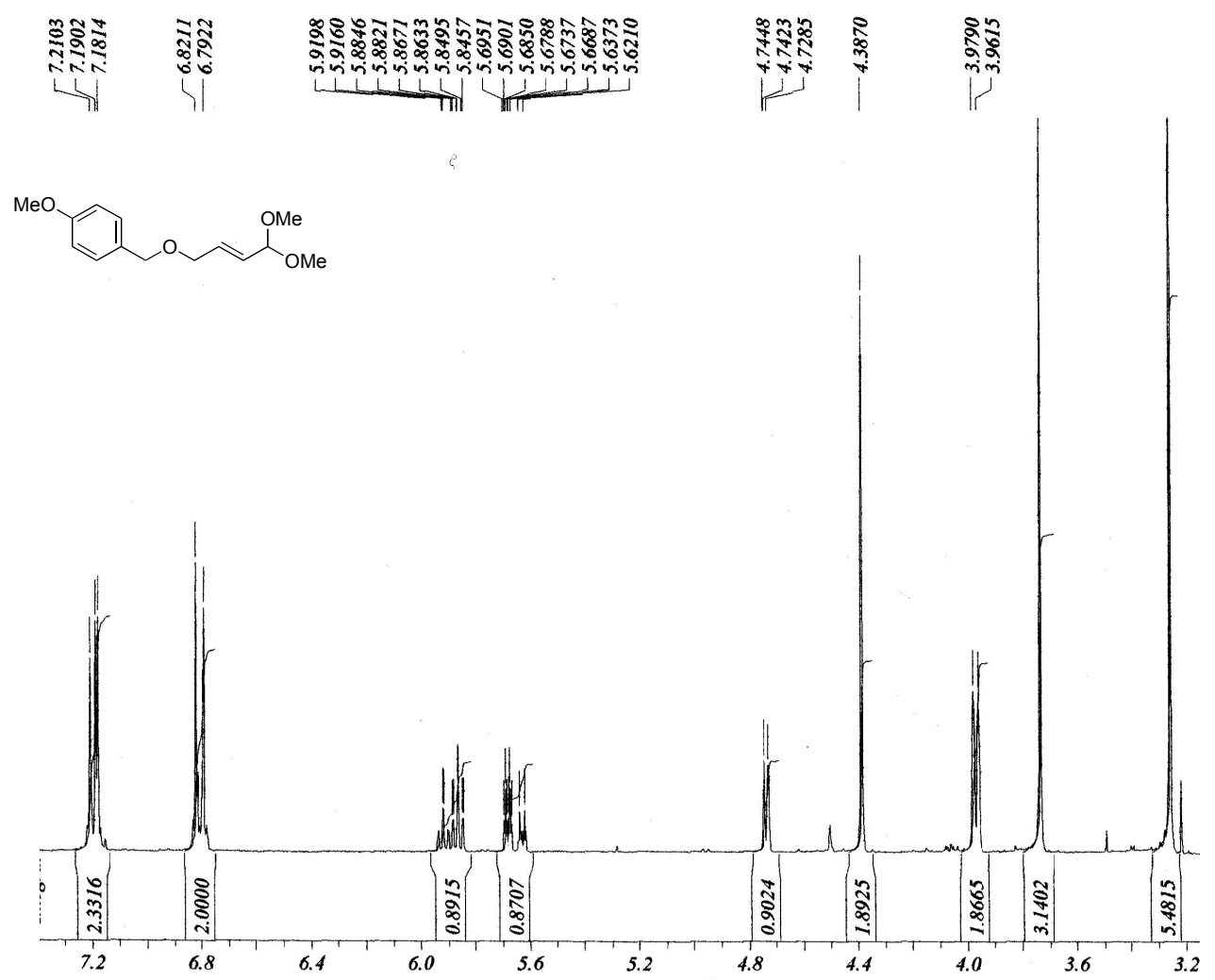

${ }^{13} \mathrm{C} \mathrm{NMR}\left(\mathrm{CDCl}_{3}, 75 \mathrm{MHz}\right)$ of $\mathbf{1 0}$
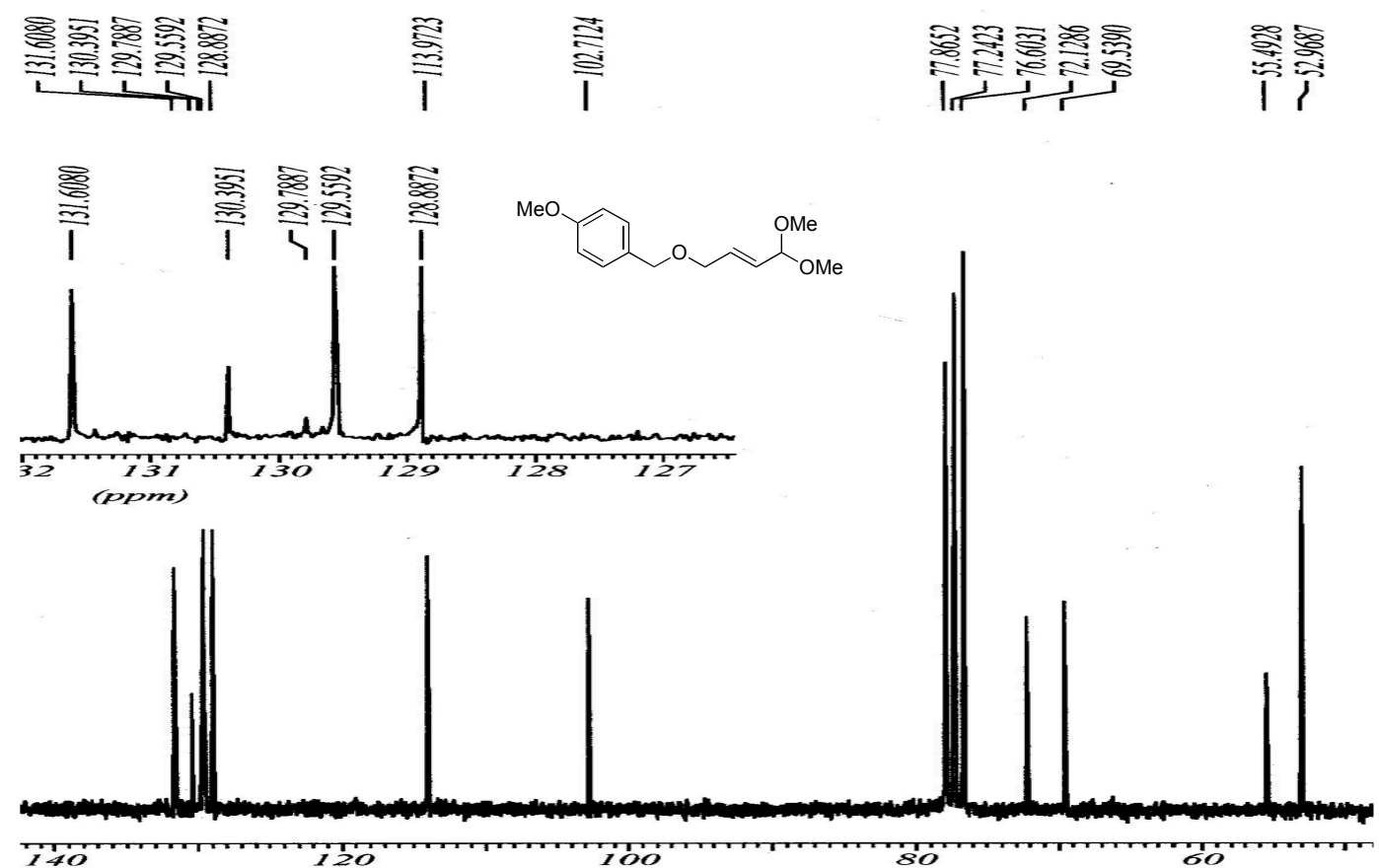


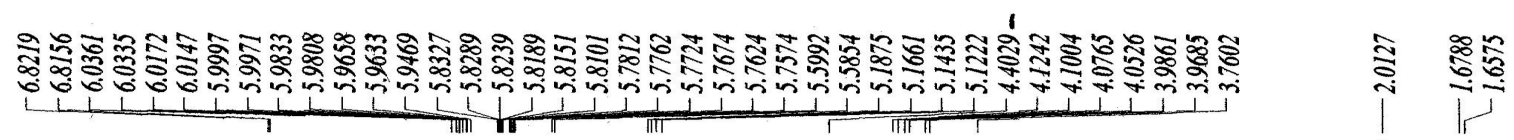

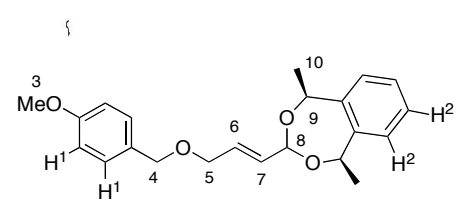

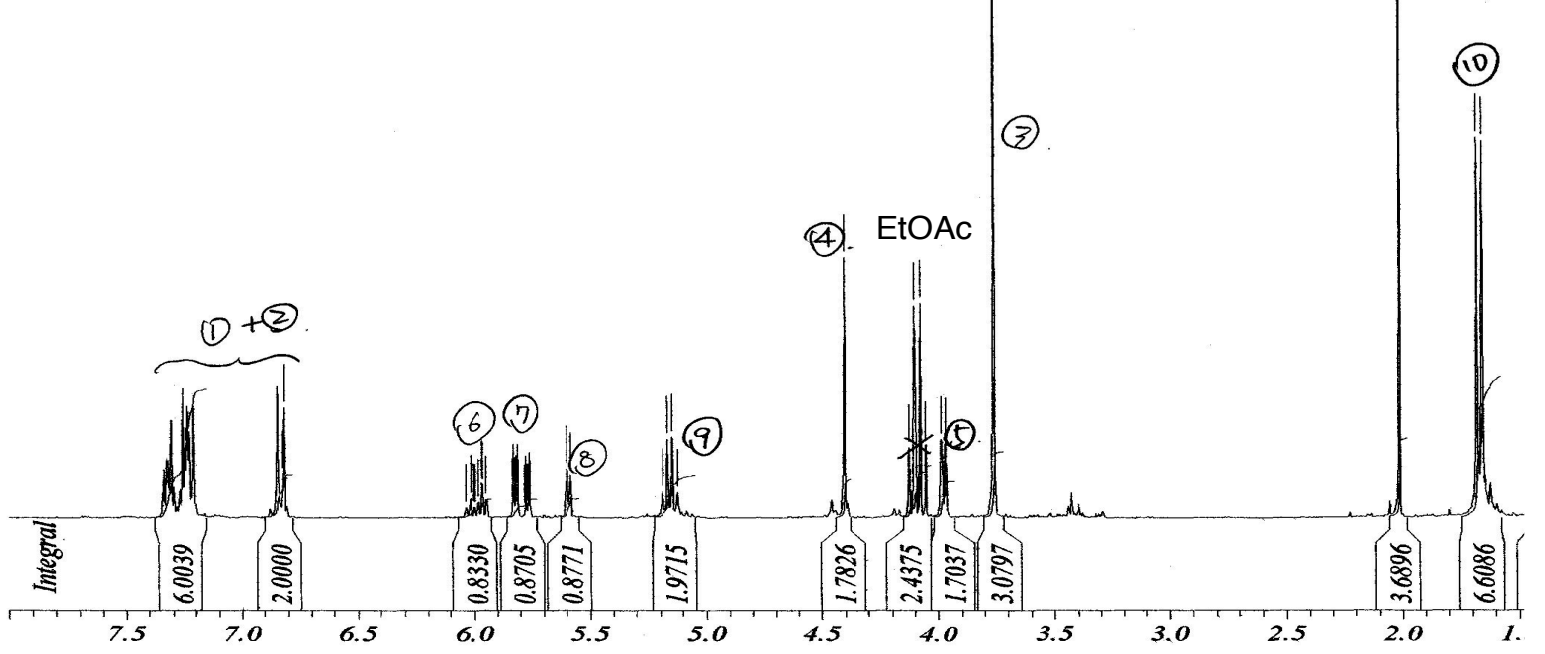

${ }^{1} \mathrm{H}$ NMR $\left(\mathrm{CDCl}_{3}, 300 \mathrm{MHz}\right)$ of $\mathbf{1 2}$
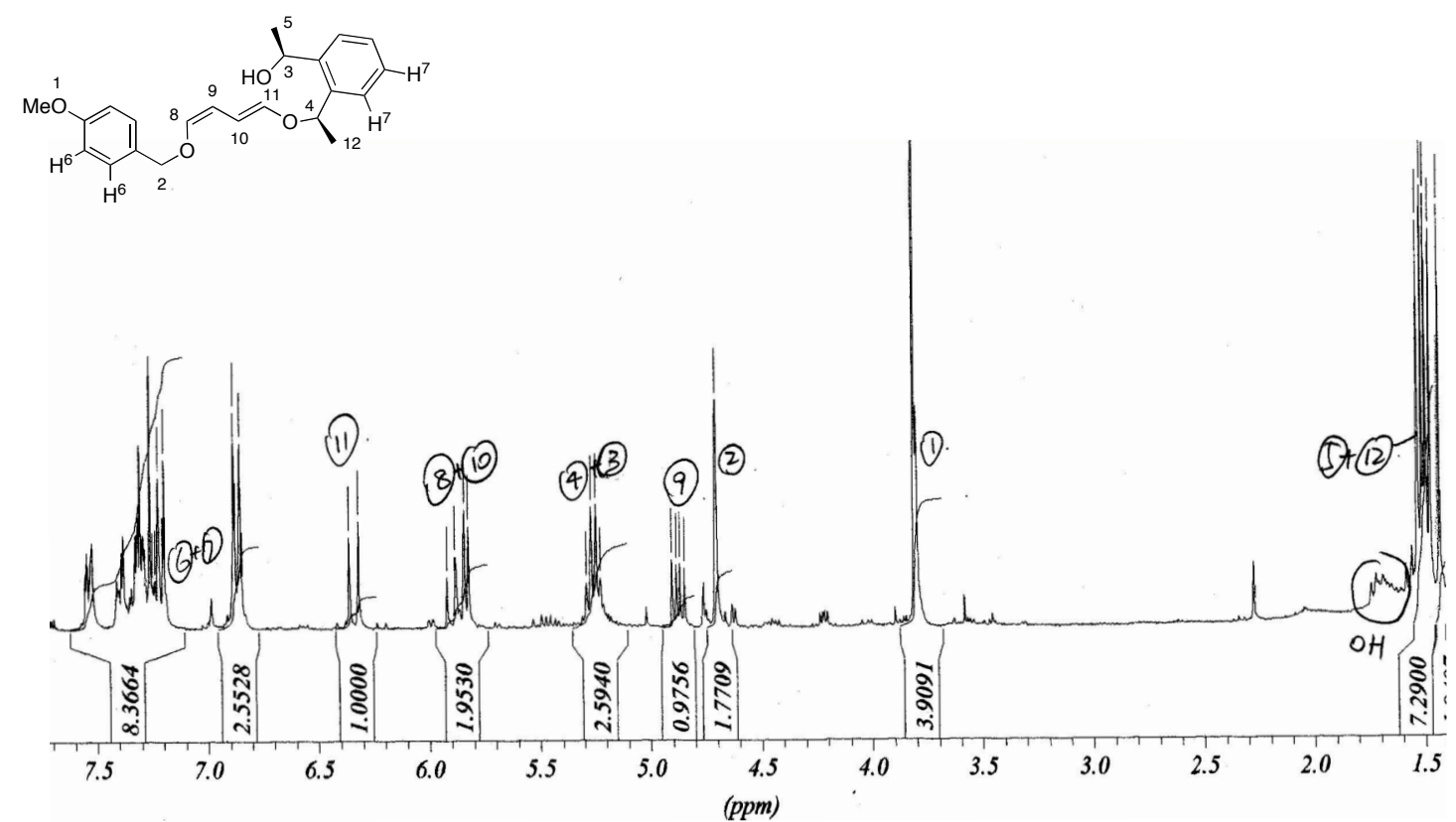